\title{
Toxicity and residual control of Plutella xylostella L. (Lepidoptera: Plutellidae) with Bacillus thuringiensis Berliner and insecticides
}

\author{
Toxicidade e controle residual de Plutella xylostella L. (Lepidoptera: Plutellidae) com Bacillus thuringiensis \\ Berliner e inseticidas
}

\author{
Carla Pedroso de Moraes ${ }^{\mathrm{I}}$ Luis Amilton Foerster ${ }^{\mathrm{II}}$
}

\section{ABSTRACT}

Plutella xylostella $L$. is the most important worldwide pest of cruciferous plants and indiscriminate use of insecticides has led to the resistance of the species to different groups. This research was conducted to compare the toxicity and persistence of two strains of Bacillus thuringiensis to P. xylostella larvae. Concentrations between 125 and $500 \mathrm{~g} 100 \mathrm{~L}^{-1}$ of water of the commercial products were evaluated and compared to the insect growth inhibitor diflubenzuron and to the neurotoxic pyrethroid deltamethrin. The efficacy of the insecticides was compared between treated plants kept indoor greenhouse and outdoor. Third instar larvae were more susceptible to $\boldsymbol{B}$. thuringiensis than first instar ones. Agree and Dipel showed similar control rates of third instars until 10 days after treatment, but on the $15^{\text {th }}$ day, Agree was significantly more efficient than Dipel. Both $\boldsymbol{B}$. thuringiensis formulations showed a reduction in mortality after 10 days when the treated plants were exposed to natural weather conditions in comparison to the same treatments kept inside greenhouse. Dimilin $\left(100 \mathrm{~g} 100 \mathrm{~L}^{-1}\right.$ of water) and deltamethrin (30ml of commercial product $100 \mathrm{~L}^{-1}$ of water) were not efficient to control third instar larvae of $\boldsymbol{P}$. xylostella. This inefficiency cannot be attributed to a resistant population of $\boldsymbol{P}$. xylostella since the larval population used in the experiments was not subjected to insecticide pressure, once the crop was organically cultivated all year round. The results showed that both formulations of $\boldsymbol{B}$. thuringiensis are sound alternatives for the control of the diamondback moth in organically conducted cruciferous crops, considering the high residual control provided under subtropical weather conditions.

Key words: diamondback moth, bioinsecticide, entomopathogens, residual persistance.
RESUMO

Larvas de Plutella xylostella L. são as principais pragas de crucíferas cultivadas e o uso excessivo e indiscriminado de inseticidas tem levado a resistência da espécie para diferentes grupos de inseticidas. Este trabalho foi conduzido para comparar a toxicidade de duas formulações de Bacillus thuringiensis para larvas de primeiro e terceiro ínstar de $\boldsymbol{P}$. xylostella. Concentrações entre 125 e $500 \mathrm{~g}_{100 \mathrm{~L}^{-1}}$ de água do produto comercial foram avaliadas e comparadas com o inibidor do crescimento diflubenzuron e com o piretroide deltametrina. A eficiência dos inseticidas foi comparada em plantas tratadas $e$ mantidas dentro e fora da casa de vegetação. Larvas de terceiro ínstar foram mais suscetíveis a B. thuringiensis do que larvas de primeiro ínstar. Agree e Dipel apresentaram taxas de controle semelhantes até 10 dias após a aplicação, porém após 15 dias, Agree foi significativamente mais eficiente do que Dipel. Ambas as formulações apresentaram uma redução na mortalidade larval quando as plantas foram expostas às condições climáticas em comparação aos mesmos tratamentos mantidos em casa de vegetação. Dimilin (100g $100 \mathrm{~L}^{-1}$ de água) e deltametrina $(30 \mathrm{ml}$ de produto comercial $100 L^{-1}$ de água) não foram eficientes para o controle de lagartas de terceiro ínstar de P. xylostella. Tal ineficiência não pode ser atribuída a um possível efeito de resistência da população de $\boldsymbol{P}$. xylostella a esses produtos, uma vez que a colônia da espécie utilizada nos experimentos não estava sujeita à pressão de seleção, por se tratar de uma população coletada em área conduzida organicamente durante todo o transcorrer do ano. Os resultados mostram que as duas formulações de $\boldsymbol{B}$. thuringiensis são alternativas viáveis para o controle de $\boldsymbol{P}$. xylostella em cultivo orgânico de crucíferas, tendo em vista o expressivo controle residual observado para as condições climáticas dos subtrópicos.

Palavras-chave: traça-das-crucíferas, bioinseticida, entomopatógenos, persistência residual.

'Programa de Pós-graduação em Agronomia, Produção Vegetal, Universidade Federal do Paraná (UFPR), 81531-990, Curitiba, PR, Brasil. E-mail: kalengagri@yahoo.com.br. Autor para correspondência.

"Departamento de Zoologia, UFPR, Curitiba, PR, Brasil. 


\section{INTRODUCTION}

The diamondback moth, Plutella xylostella (L.) (Lepidoptera: Plutellidae) is a cosmopolitan pest which causes heavy damage to cruciferous plants, especially in cabbage, both in Brazil (CASTELOBRANCO etal., 1996; FRANÇA \& MEDEIROS, 1998), and elsewhere (TALEKAR\& SHELTON, 1993; GODIN\& BOIVIN, 1998). After the second instar, the larvae bore into leaf tissues of cabbage heads thus reducing the commercial value of the product. Damage can reach $100 \%$ of the heads, which are then classified as inadequate for marketing (OOI \& KELDERMAN, 1979).According to BARROS etal.(1993), there is a straight correlation between the phenological development of the plants and damage level. Due to the irreversible condition of the damage, control measures are adopted before the beginning of head development.

Chemical control is the main method to reduce the damage caused by the diamondback moth larvae; usually the number of insecticide applications can reach as much as 15 or 20, independently of the presence of larvae in the field (LIM, 1990; CARBALLO, 1992; SAMPSON, 1992). As a result of excessive use of insecticides, diamondback moth is among the lepidopteran species with largest number of records of resistance to active ingredients and there are reports of more than 50 insecticides (VASQUEZ, 1995), including Bacillus thuringiensis (FERRÉ et al., 1991; TABASHNIK et al., 1994a, b).

Biological methods based on the use of predators, parasitoids and entomopathogenic microorganisms are sound alternatives to overcome the inefficiency of chemical control (MONNERAT \& BORDAT, 1998; SILVA-TORRES et al., 2010a,b; 2011). Bioinsecticides based on B. thuringiensis are commercially produced since 1970 and at present represent over $90 \%$ of the market for biological products for pest control (DIAS et al., 2004).

In this research the efficiency and persistence of two formulations of $\boldsymbol{B}$. thuringiensis were evaluated and compared to an insect growth inhibitor and a neurotoxic pyrethroid insecticide on first and third instar larvae of $\boldsymbol{P}$. xylostella up to 15 days after application. The persistence of the insecticides was compared in plants kept indoor and outdoor a greenhouse.

\section{MATERIAL AND METHODS}

The larvae used in the experiments were obtained from a colony kept in the laboratory at $20 \pm 1^{\circ} \mathrm{C}$ and photo phase of 12:12 hours (D:L). Larvae were collected in a cauliflower crop in Colombo, Paraná and were reared in laboratory for ten generations before being used in the experiments. Field collected larvae were continuously introduced in the colony to renew the genetic pool of the colony. The larvae were collected in an organic crop, and thus not subjected to insecticide pressure. The treatments were conducted on Fuyutoyo cabbage plants grown in 20L polyethylene pots maintained in a greenhouse. The insecticides were sprayed at pre-heading stage, 45 days after the plants were transplanted to the pots.

The following treatments in $\mathrm{g}$ or $\mathrm{ml}$ of commercial product $100 \mathrm{~L}^{-1}$ of water were applied with a $2 \mathrm{~L}$ manually-pressurized sprayer to the leaves of cabbage plants until the leaves were wet: Dipel (B. thuringiensis var. kurstaki) (500g); Agree (B. thuringiensis var. aizawai GC 91, transconjugated (hybrid) with toxins of $\boldsymbol{B}$. thuringiensis var. kurstaki) (125g, 250g and 500g); diflubenzuron (Dimilin 25PM) (100g); deltamethrin (Decis 25CE) (30ml) and a control treatment sprayed only with water. A preliminary experiment showed that the inclusion of the adjuvant Agral to the solutions did not improve the efficiency of the insecticides. Based on the results obtained in the first experiment, another one was conducted to evaluate a lower concentration of Agree

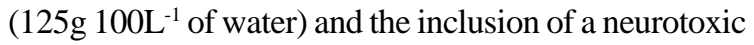
pyrethroid, deltamethrin (30ml 100L $\mathrm{L}^{-1}$ of water). Each treatment consisted of 10 replications (plants) and after the leaves had dried, two hours after spraying, one leaf was removed from each plant and placed in a $15 \mathrm{~cm}$ diameter Petri dish lined with a paper towel to offer the larvae. Mortality was assessed on first and third instar larvae. Ten larvae were placed on each treated leaf which together with an untreated control were kept in a climatic chamber at $20 \pm 1^{\circ} \mathrm{C}, 12: 12$ hours D:L photophase and relative humidity of $60 \pm 10 \%$. After three, six, 10 and 15 days after application (DAA) a new set of leaves were collected from the previously treated plants and exposed to another set of larvae of similar ages to assess the residual effect of the insecticides. Due to the slower action of entomopathogenous insecticides, evaluation of mortality was assessed during four days after exposure of the larvae to the treated leaves.

In order to compare the residual effect of the insecticides between plants grown outdoor under the natural weather conditions (precipitation, wind and solar radiation) and plants kept indoor another experiment employing a similar procedure was carried out and larval mortality was compared between plants maintained under the two environmental conditions.

The experiments were conducted in a completely randomized design, in a factorial arrangement with four (insecticides) $x$ five (residual times) treatments. Analysis of variance (ANOVA) was used to compare 
treatment and time effects within each experiment. Means classification were performed using Tukey's least significant difference test $(\mathrm{P}<0.05)$. Treatment efficiencies were compared by correcting mortalities through Abbott's formula (ABBOTT, 1925). Normality and homogeneity of variance of the data was checked using Shapiro-Wilk's test and Levene's test, respectively.

\section{RESULTS AND DISCUSSION}

Agree and Dipel were more efficient than diflubenzuron for first instar larvae $(\mathrm{F}=153.7 ; \mathrm{P}<0.001 ; \mathrm{df}=3)$ (Table 1). The toxicity of Dipel to third instar larvae decreased from $73.4 \%$ on the third day after application to $36.7 \%$ after 15 days post treatment (Table 1 ). For Agree no statistical differences were recorded among the intervals after application, reaching a highest value of $89.0 \%$ mortality in the sixth day after application. First instar larvae of $\boldsymbol{P}$. xylostella were significantly more susceptible to Agree and Dipel than to diflubenzuron for all evaluation periods after treatment $(\mathrm{F}=2.2 ; \mathrm{P}=0.071 ; \mathrm{df}=4)$.

On third instar larvae, the toxicity of both formulations of $\boldsymbol{B}$. thuringiensis was higher than on first instar larvae (Table 2). During the first instar, the larvae develop endophytically, a condition of low exposure of the larvae on the treated surface, whereas in the third instar the larvae remain on the leaf surface and ingest a higher amount of insecticide than first instar larvae, as observed by CARVALHO et al. (2010).

There was a significant difference among the insecticides used against third instar larvae $(\mathrm{F}=2.4$; $\mathrm{P}<0.001$; $\mathrm{df}=3$ ), as well as among the residual periods evaluated $(\mathrm{F}=467.9 ; \mathrm{P}=0.048 ; \mathrm{df}=4)$. The toxicity of Dipel to third instar larvae dropped from $85.0 \%$ on the sixth day after application to $56.8 \%$ after 15 days post treatment (Table 2). For Agree the highest mortality was recorded 10 days after application (90.0\%) while the lowest rate of control was recorded on the day of application (69.0\%). The effect of diflubenzuron did not differ from the untreated control and the corrected mortality was below $20 \%$ in all residual periods evaluated (Table 2).

According to ARONSON et al. (1986), the symptoms of larval intoxication appear soon after the ingestion of the toxic proteins of $\boldsymbol{B}$. thuringiensis and thus damage is reduced even before larval death due to the penetration of the spores through the perithrophic membrane lining the mesenteron.

Table 3 shows third instar mortality in plants exposed to natural weather conditions and those kept inside a greenhouse after insecticide application. During the experimental period, plants were exposed to solar radiation and rain $(46.8 \mathrm{~mm})$. Like diflubenzuron in the previous experiment, deltamethrin did not provide effective control of the larvae, even when plants were kept inside the greenhouse(Table 3). CASTELOBRANCO et al. (2001) recorded a complete failure of deltamethrin to control larvae of $\boldsymbol{P}$. xylostella, with less than six percent of mortality, indicating a possible occurrence of resistance to this product.

All treatments with Agree were highly efficient up to ten days after application, except the lower concentration after being kept under natural conditions for 10 days (Table 3). After 15 days of insecticide spray, it was found that all treatments had lost their efficiency $(\mathrm{F}=39.7 ; \mathrm{P}<0.001 ; \mathrm{df}=15)$. The daily mortality of larvae during four days after residues 0,10 and 15 days old shows the gradual loss of persistency of the lower dosage of Agree both in relation to the age of the residue and to the effect of exposing the treated plants to solar radiation and rain (Figure 1). The higher concentration of Agree only lost its efficiency 15DAA, with a drastic reduction in comparison to shorter residual periods, even in plants protected from rain and solar radiation. CASTELO BRANCO (1999) obtained 97\% mortality of second instar $\boldsymbol{P}$. xylostella in laboratory tests with $\boldsymbol{B}$. thuringiensis var. kurstaki (500 $\left.\mathrm{ml} \mathrm{ha}^{-1}\right)$ and aizawai $\left(350 \mathrm{ml} \mathrm{ha}^{-1}\right)$. However when the same treatments were applied in the field, they were not efficient against larvae and the failure in the

Table 1 - Mean ( \pm EP) mortality (\%) of first instar larvae of Plutella xylostella after exposure for four days to cabbage leaves containing insecticide residues up to 15 days after application.

\begin{tabular}{|c|c|c|c|c|c|}
\hline Treatment & Zero $^{1}$ & Three & Six & Ten & Fifteen \\
\hline Control & $7.0 \pm 1.53 \mathrm{Ac}$ & $8.0 \pm 1.33$ Aс & $8.0 \pm 1.33 \mathrm{Ac}$ & $8.0 \pm 1.33$ Aс & $8.0 \pm 1.33 \mathrm{Ac}$ \\
\hline Agree & $72.10 \pm 7.90 \mathrm{Aa}$ & $78.9 \pm 8.68 \mathrm{Aa}$ & $89.0 \pm 4.06 \mathrm{Aa}$ & $81.8 \pm 6.12 \mathrm{Aa}$ & $83.9 \pm 5.43 \mathrm{Aa}$ \\
\hline Dipel & $63.7 \pm 6.40 \mathrm{Aa}$ & $73.4 \pm 9.27 \mathrm{Aa}$ & $65.0 \pm 4.43 \mathrm{Ab}$ & $72.9 \pm 5.19 \mathrm{Aa}$ & $36.7 \pm 6.21 \mathrm{Bb}$ \\
\hline Diflubenzuron & $33.4 \pm 4.81 \mathrm{Ab}$ & $36.2 \pm 7.84 \mathrm{Ab}$ & $55.8 \pm 6.77 \mathrm{Ab}$ & $42.1 \pm 6.52 \mathrm{Ab}$ & $54.2 \pm 4.41 \mathrm{Ab}$ \\
\hline
\end{tabular}

\footnotetext{
${ }^{1}$ Means followed by the same low case letters in the columns and upper case letters in the rows do not differ according to Tukey's test $(\mathrm{P}>0.05)$.
} 
Table 2 - Mean ( \pm EP) mortality (\%) of third instar larvae of Plutella xylostella after exposure for four days to cabbage leaves containing insecticide residues of different ages up to 15 days after application.

\begin{tabular}{|c|c|c|c|c|c|}
\hline Treatment & Zero & Three & Six & Ten & Fifteen \\
\hline Control & $31.0 \pm 2.33 \mathrm{Ab}$ & $16.0 \pm 2.21 \mathrm{Bb}$ & $15.0 \pm 1.67 \mathrm{Bb}$ & $10.0 \pm 2.58 \mathrm{Bb}$ & $12.0 \pm 2.91 \mathrm{Bc}$ \\
\hline Agree & $69.0 \pm 2.33 \mathrm{Ba}$ & $84.0 \pm 2.21 \mathrm{Aa}$ & $85.0 \pm 1.67 \mathrm{Aa}$ & $90.0 \pm 2.58$ Aа & $84.5 \pm 3.58 \mathrm{Aa}$ \\
\hline Dipel & $67.6 \pm 2.68 \mathrm{ABa}$ & $79.0 \pm 4.89 \mathrm{Aa}$ & $85.0 \pm 1.67 \mathrm{Aa}$ & $84.3 \pm 4.31 \mathrm{Aa}$ & $56.8 \pm 9.38 \mathrm{Bb}$ \\
\hline Diflubenzuron & $17.0 \pm 3.00 \mathrm{Ac}$ & $13.0 \pm 2.60 \mathrm{Ab}$ & $11.0 \pm 3.48 \mathrm{Ab}$ & $12.9 \pm 5.96 \mathrm{Ab}$ & $15.0 \pm 4.77 \mathrm{Ac}$ \\
\hline
\end{tabular}

${ }^{1}$ Means followed by the same lower case letters in columns and upper case in rows do not differ by Tukey’s test (P>0.05).

control of the diamondback moth was attributed to the fast degradation of $\boldsymbol{B}$. thuringiensis in natural weather conditions. HADDAD et al. (2005) evaluated the field persistence of $\boldsymbol{B}$. thuringiensis and determined a halflife of 16.5 hours for the recommended dosage. One day after treatment, only $78 \%$ of the spores remained on the leaf surface. Our results show that in areas with less solar radiation the persistence of $\boldsymbol{B}$. thuringiensis spores is higher than in tropical regions.

The results showed that the formulation of B. thuringiensis containing aizawai and kurstaki lineages is more efficient than the kurstaki lineage alone. Although high mortality was attained with concentrations as low as $125 \mathrm{~g}$ of commercial product $100 \mathrm{~L}^{-1}$ of water, the residual effect is shorter than 10 days, while the concentration of $500 \mathrm{~g}$ of Agree was efficient for up to 15 days after application. The toxicity of deltamethrin to larvae of $\boldsymbol{P}$. xylostella was significantly lower than that of $\boldsymbol{B}$. thuringiensis, even in the lower concentrations of the bioinsecticide evaluated.
The relatively high persistence of the toxic effects of $\boldsymbol{B}$. thuringiensis in comparison to data available in the literature (CASTELOBRANCO, 1999; HADDAD et al., 2005) suggests that the performance of this bioinsecticide is less affected by weather conditions in the subtropics than in warmer tropical areas, where solar radiation is described as affecting the persistence of the spores of B. thuringiensis (POLANCZYK\&ALVES, 2003).

The high efficiency of $\boldsymbol{B}$. thuringiensis recorded in our experiments show that the lineage of $\boldsymbol{P}$. xylostella occurring in Southern Brazil has not acquired resistance to this microbial insecticide, as reported by CASTELO BRANCO \& GATEHOUSE (2001) in the Federal District, Brazil.

Considering the need for insecticide options to be employed in organic horticultural crops, the results showed that $\boldsymbol{B}$. thuringiensis is a highly useful alternative for the control of $\boldsymbol{P}$. xylostella. The use of $\boldsymbol{B}$. thuringiensis in greenhouses should be based on previous samplings that indicated the need for control measures. In closed environments the selection of resistant populations is

Table 3 - Mean ( \pm EP) mortality of third instar larvae of Plutella xylostella in plants treated with insecticides and kept either inside a greenhouse or exposed to weather conditions outside the greenhouse for 15 days after insecticide application.

\begin{tabular}{|c|c|c|c|c|c|}
\hline Treatment & $E^{*}$ & Zero $^{1}$ & Five & Ten & Fifteen \\
\hline Control & I & $10.0 \pm 5.48 \mathrm{Aa}$ & $10.0 \pm 3.16 \mathrm{Aa}$ & $18.0 \pm 8.00 \mathrm{Aa}$ & $0.0 \pm 0.00 \mathrm{Aa}$ \\
\hline Control & $\mathrm{O}$ & $6.0 \pm 4.00 \mathrm{Aa}$ & $12.0 \pm 2.00 \mathrm{Aa}$ & $14.0 \pm 6.78 \mathrm{Aa}$ & $2.0 \pm 2.00 \mathrm{Aa}$ \\
\hline Deltamethrin & I & $25.3 \pm 9.99 \mathrm{ABa}$ & $48.9 \pm 8.86 \mathrm{Aa}$ & $24.0 \pm 6.32 \mathrm{ABa}$ & $22.0 \pm 12.41 \mathrm{ABa}$ \\
\hline Deltamethrin & $\mathrm{O}$ & $12.9 \pm 3.95 \mathrm{Ba}$ & $26.8 \pm 8.86 \mathrm{ABb}$ & $11.8 \pm 0.92 \mathrm{Ba}$ & $2.0 \pm 2.00 \mathrm{Bb}$ \\
\hline Agree $125 \mathrm{~g}$ & I & $90.0 \pm 5.48 \mathrm{Aa}$ & 87.5 \pm 5.36 Aа & $71.2 \pm 12.77 \mathrm{Aa}$ & $34.0 \pm 11.66 \mathrm{Ba}$ \\
\hline Agree $125 \mathrm{~g}$ & $\mathrm{O}$ & $94.0 \pm 4.00 \mathrm{Aa}$ & $79.1 \pm 3.52 \mathrm{Aa}$ & $36.0 \pm 7.02 \mathrm{Bb}$ & $2.0 \pm 2.00 \mathrm{Bb}$ \\
\hline Agree 250g & I & $90.0 \pm 5.48 \mathrm{Aa}$ & $90.0 \pm 3.16$ Аа & $78.6 \pm 9.59 \mathrm{ABa}$ & $28.0 \pm 8.00 \mathrm{BCa}$ \\
\hline Agree $250 \mathrm{~g}$ & $\mathrm{O}$ & $94.0 \pm 4.00 \mathrm{Aa}$ & $85.8 \pm 2.59 \mathrm{Aa}$ & $70.6 \pm 13.12 \mathrm{ABa}$ & $12.9 \pm 6.53 \mathrm{Ca}$ \\
\hline Means $( \pm \mathrm{EP})$ & I & $53.8 \pm 8.97 a$ & 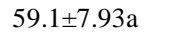 & 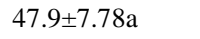 & $21.0 \pm 4.99 a$ \\
\hline Means $( \pm E P)$ & $\mathrm{O}$ & $51.7 \pm 9.88 a$ & $50.9 \pm 7.70 a$ & $33.1 \pm 7.36 b$ & $4.7 \pm 2.01 b$ \\
\hline
\end{tabular}

${ }^{1}$ Means followed by the same lower case letters in columns and upper case in rows do not differ by Tukey's test ( $\mathrm{P}>0.05$ ).

* E- Environment; I- Inside greenhouse; O- Outside greenhouse 

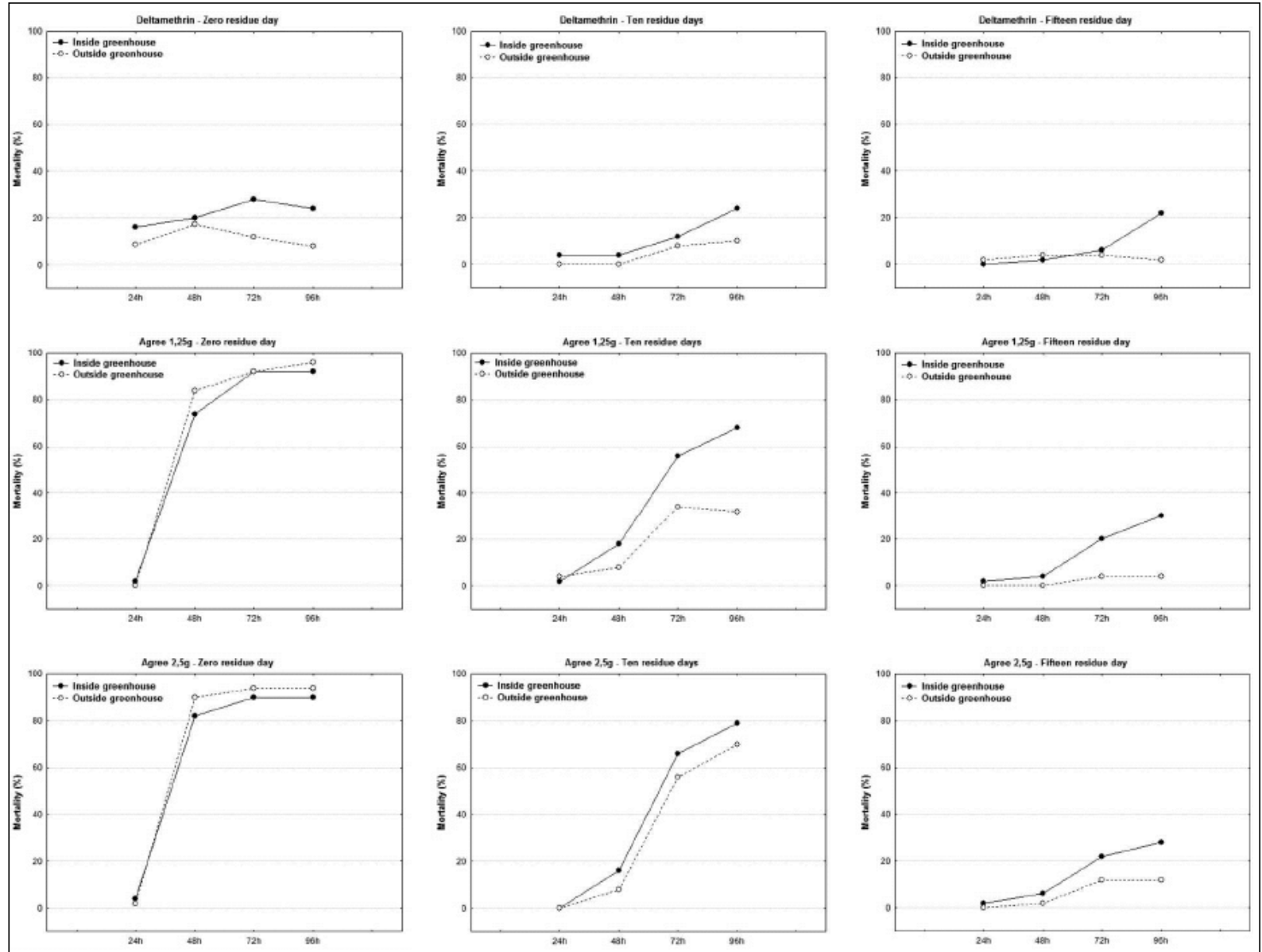

Figure 1 - Mortality of third instar larvae of Plutella xylostella to the insecticides during the exposition time in each of the three residual ages after spraying.

more frequent because the migration of susceptible individuals is reduced in comparison to open field populations (TABASHNIK et al., 2000). The presence of diamondback moth in brassicaceous plants can be monitored by means of pheromone traps (IMENES et al., 1999) to indicate the proper time for insecticide use. Natural enemies are not affected by $\boldsymbol{B}$. thuringiensis (MONNERAT et al., 2000) and adult parasitoids walking on treated surfaces are able to find and parasitize larvae not intoxicated, thus complementing the action of the insecticide. Moreover, B. thuringiensis can be included in insecticide rotation programs especially in greenhouses, as an alternative to neurotoxic molecules to prevent or delay the appearance of resistant strains of P. xylostella (CASTELO BRANCO et al., 2003; RAYMOND et al., 2007).

\section{ACKNOWLEDGEMENTS}

The researches are grateful to the Brazilian Federal Agency for Support and Evaluation of Graduate Education
(CAPES) for the scholarship to the first author and to Mr. Iain Laidler for the critical revision of the English.

\section{REFERENCES}

ABBOTT, W.S. A method of computing the effectiveness of an insecticide. Journal of Economic Entomology, v.18, p.265267, 1925.

ARONSON, A.I. et al. Bacillus thuringiensis and related insect pathogens. Microbiology and Molecular Biology Reviews, v.50, p.1-24, 1986.

BARROS, R. et al. Controle químico da traça-das-crucíferas Plutella xylostella (L.) (Lepidoptera: Plutellidae), em repolho. Anais da Sociedade Entomológica do Brasil, v.22, p.463-469, 1993.

CARBALLO, V.M. Investigación sobre manejo integrado de Plutella xylostella L. en el cultivo de repolho en Costa Rica. Cerba, v.33, p.617-622, 1992.

CARVALHO, J.S. et al. Efeito de sinigrina aplicada em folhas de brássicas sobre características biológicas de Plutella xylostella (L.) (Lepidoptera: Plutellidae). Acta Scientiarum Agronomy, v.32, p.15-20, 2010.

Ciência Rural, v.42, n.8, ago, 2012. 
CASTELO BRANCO, M. et al. Nível de dano de traça-dascrucíferas em repolho. Horticultura Brasileira, v.14, p.154157, 1996.

CASTELO BRANCO, M.; GATEHOUSE, A.G. A survey of insecticide susceptibility in Plutella xylostella (L.) (Lepidoptera: Yponomeutidae) in the Federal District, Brazil. Neotropical Entomology, v.30, p.327-332, 2001. Available from: <http:// www.scielo.br/scielo.php?script $=$ sci_arttext\&pid $=$ S1519566X2001000200019>. Accessed: Jun. 13, 2011. doi: 10.1590/ S1519-566X2001000200019.

CASTELO BRANCO, M. et al. Avaliação da suscetibilidade a inseticidas de populações da traça-das-crucíferas de algumas áreas do Brasil. Horticultura Brasileira, v.21, p.549-552, 2003. Available from: <http://www.scielo.br/scielo.php?pid=S010205362003000300027\&script=sci_arttext $>$. Accessed: Jun. 10, 2011. doi: $10.1590 /$ S0102-05362003000300027.

CASTELO BRANCO, M. Avaliação da eficiência de formulações de Bacillus thuringiensis para o controle de traça-das-crucíferas em repolho no Distrito Federal. Horticultura Brasileira, v.17, p.237-240, 1999.

CASTELO BRANCO, M. et al. Uso de inseticidas para o controle da traça-do-tomateiro e traça-das-crucíferas: um estudo de caso. Horticultura Brasileira, v.19, p.60-63, 2001. Available from: $<$ http://www.scielo.br/scielo.php?script=sci_arttext\&pid=S010205362001000100012>. Accessed: Jul. 13, 2011. doi: 10.1590/ S0102-05362001000100012.

DIAS, D.G.S. et al. Avaliação de larvicidas de origem microbiana no controle da traça-das-crucíferas em couve-flor. Horticultura Brasileira, v.22, p.553-556, 2004. Available from: <http:/www.scielo.br/ scielo.php?pid=S0102-05362004000300010\&script=sci_arttext $>$. Accessed: Jul. 12, 2011. doi: 10.1590/S0102-05362004000300010.

FERRÉ, J. et al. Resistance to the Bacillus thuringiensis bioinsecticide in a field population of Plutella xylostella is due to a change in a midgut membrane receptor. Proceedings of the National Academy of Science, v.88, p.5119-5123, 1991.

FRANÇA, F.H.; MEDEIROS, M.A. Impacto de combinação de inseticidas sobre a produção de repolho e parasitóides associados com a traça-das-crucíferas. Horticultura Brasileira, v.16, p.132-135, 1998.

GODIN, C.; BOIVIN, G. Seasonal occurence of lepidopterous pests of cruciferous crops in Southwestern Quebec in relation to degree-day accumulations. Canadian Entomologist, v.130, p.173-185, 1998.

HADDAD, M.L. et al. Field persistence of Bacillus thuringiensis on maize leaves (Zea mays L.). Brazilian Journal of Microbiology, v.36, p.309-314, 2005.

IMENES, S.D.L. et al. Avaliação da atratividade de feromônio sexual sintético da traça das crucíferas, Plutella xylostella (L.) (Lepidoptera: Plutellidae), em cultivo orgânico de repolho. In: REUNIÃO ANUAL DO INSTITUTO BIOLÓGICO, 12., 1999, São Paulo, SP. Arquivos do Instituto Biológico. São Paulo: Instituto Biológico, 1999. V.66, 166p.

LIM, G.S. Overview of vegetable IPM in Asia. FAO Plant Protection Bulletin, v.38, p.73-87, 1990.

MONNERAT, R.G.; BORDAT, D. Influence of HD-1 Bacillus thuringiensis spp. kurstaki on the developmental stages of
Diadegma sp. (Hymenoptera: Ichneumonidae) parasitoid of diamondback moth (Lepidoptera: Yponomeutidae). Journal of Applied Entomology, v.122, p.49-51, 1998.

MONNERAT, R.G. et al. Efeito de Bacillus thuringiensis Berliner e inseticidas químicos sobre a traça-das-crucíferas, Plutella xylostella (L.) (Lepidoptera:Yponomeutidae) e seus parasitóides. Anais da Sociedade Entomológica do Brasil, v.29, p.723730, 2000.

OOI, P.A.C.; KELDERMAN, W. The biology of three common pests of cabbage in Cameron Higlands, Malaysia. Malaysian Agricultural Journal, v.52, p.85-101, 1979.

POLANCZYK, R.; ALVES, S.B. Bacillus thuringiensis: uma breve revisão. Agrociência, v.2, p.1-10, 2003.

RAYMOND, E. et al. Exploiting pathogens and their impact on fitness costs to manage the evolution of resistance to Bacillus thuringiensis. Journal of Applied Ecology, v.44, p.768-780, 2007.

SAMPSON, C. Producción de repolho en Belice: programa de investigación para el control de la palomilla dorso de diamante. Cerba, v.33, p.623-628, 1992.

SILVA-TORRES, C.S.A. et al. Parasitismo de traça-dascrucíferas por Oomyzus sokolowskii. Pesquisa Agropecuária Brasileira, v.45, p.638-645, 2010a. Available from: <http:// www.scielo.br/pdf/pab/v45n7/02.pdf > . Accessed: Oct. 02, 2011. doi.org/10.1590/SO100-204X2010000700002.

SILVA-TORRES, C.S.A. et al. New records of natural enemies of Plutella xylostella (L.) (Lepidoptera: Plutellidae) in Pernambuco, Brazil. Neotropical Entomological, v.39, p.835-838, 2010b. Available from: <http://www.scielo.br/scielo.php?pid=S1519566X2010000500028\&script=sci_arttext $>$. Accessed: Oct. 02, 2011. doi: 10.1590/S1519-566X2010000500028.

SILVA-TORRES, C.S.A. et al. Can cruciferous agroecosystems grown under variable conditions influence biological control of Plutella xylostella (Lepidoptera: Plutellidae). Biocontrol Science and Technology, v.21, p.625-641, 2011. Available from: <http://www.tandfonline.com/doi/full/10.1080/ 09583157.2011.568112\#tabModule>. Accessed: Oct. 02, 2011. doi. 10.1080/09583157.2011.568112.

TABASHNIK, B.E. et al. Reversal of resistance to Bacillus thuringiensis in Plutella xylostella. Proceedings of the National Academy of Science, v.91, p.4120-4124, 1994a.

TABASHNIK, B.E. et al. Cross-resistance to Bacillus thuringiensis toxin CryIF in the diamondback moth (Plutella xylostella). Applied Environmental Microbiology, v.60, p.4627-4629, 1994b.

TABASHNIK, B.E. et al. Frequency of resistance to Bacillus thuringiensis in field populations of pink bollworm. Proceedings of the National Academy of Sciences, v.97, p.12980-12984, 2000.

TALEKAR, N.S.; SHELTON, A.M. Biology, ecology and management of the diamondback moth. Annual Review of Entomology, v.38, p.275-301, 1993.

VASQUEZ, B.L. Resistance to most insecticides. In: WALKER, T.J. (Eds). Book of insect records. Gainesville: University of Florida, 1995. p.34-36. 